\title{
Exploring Business Ecosystem of Poultry Industry in Bangladesh
}

\author{
Md. Moniruzzaman*, Sheikh Morshed Jahan** \\ ${ }^{*} D B A$ (Doctor of Business Administration) Student, Institute of Business Administration, University of Dhaka \\ ${ }^{* *}$ Associate Professor, Institute of Business Administration, University of Dhaka
}

\begin{abstract}
The poultry is an emerging industry in Bangladesh. It has taken a phenomenal growth in the economy since early 1990s without making any deliberate feasibility study. Towards the GDP contribution from the agriculture sector has declined over the years but the share of livestock in agriculture has increased. Based on poultry industry a number of subindustries have developed both in input sector and output sector working as backward linkage and forward linkage along with many service providing organizations and/or institutions. All these sub-industries and institutions along with the selfintegrated components of a commercial industry such as customers, competitors, distributors, etc. are working together as live organs of biological specie. If all the organs work perfectly individually, it will lead to the complete and perfect living of a specie. Similarly if all the allied industries, industry-integrated components as well as supporting institutions and/or organizations perform properly, the whole poultry industry is expected to perform effectively and efficiently. The paper attempts to narrate how these sub-industries, service providing institutes, industry-integrated components are working to run the whole poultry industry under a concept of ecosystem inherited from a British botanist in 1930s and incorporated in 1993 by the business strategist James Moore.
\end{abstract}

Keywords: Ecosystem, DOC, backward linkage, forward linkage, hierarchy in poultry generation, five forces model.

\section{Introduction}

Traditionally Bangladesh is an agriculture-based economy. To the GDP, its contribution (agriculture and forestry) is about 12.41 percent as per statistics of 2013-14 ${ }^{1}$. At the present time beginning since early 1990s a transition is running of transforming the traditional agriculture into high-yielding production system with advanced scientific technology as well as know-how and commercializing the same. Here the commercialization may refer to cultivating a crop in a mass volume production (not producing for meeting family need for food purpose) and selling the same for earning money as earned through conducting business traditionally. For instance, in the area of Jhenidah, particularly in Kaligonj ${ }^{2}$, an upzilla town in Jhenidah district, mass level production of banana over the acres of land started in early 1980s and those generally were used to sell directly to Dhaka market through sending via truck or selling to the wholesale buyers available in the local area who were generally from Dhaka market. The main characteristic of this production system in crop may be leveled as producing in high volume and selling it to the market. Such examples may be given in many other agri-products including poultry. And the concept of agri-business in the latest format in Bangladesh in modern/recent time may be related to this form of crop production. In the language of Hossain (2013), Bangladesh's agribusiness may consist of the sectors including (i) poultry, livestock (dairy); (ii) fisheries, (iii) agricultural crops; and (iv) fruit processing and plants.

Raha $^{3}$ (n.d.) states that poultry refers to domestic birds that produce eggs, meat, manure and feathers that can be used or treated by their owners. Two types of chicken are reared commercially. One is for egg called layer and another for meat called broiler $^{4}$. Poultry works as a source of protein in the form of meat and eggs irrespective of race and religion of people. The traditional chicken is the backyard and scavenging poultry that are reared by the rural women since the ancient time (Alders and Pym 2009). Another chicken is the crossbred and similar to local chicken is the Sonali which requires less care and attention (Saleque and Saha 2013). It comprises 30\% of total broiler and layer production (Haque et al. 2011). It was introduced during 1996-2000 in the northern part of the country via two projects. The share of commercial strain of chicken and family poultry was 50:50 in egg production while for meat production it was 60:40 in Banladesh (Bhuiyan 2011).

The pioneer company in commercial poultry in Bangladesh is Eggs and Hens Ltd. It started business in 1954. Government sponsored company Biman Poultry Complex after independence had also a role in the introduction of the industry. The industry took the smooth takeoff during 1990s with heavy investment in itself from the private sector. The estimated total investment in the sector is $\$ 3.00$ billion equivalent to BDT 24,000 crore $^{5}$ with an employment base of 6.0 million people (Huqu et al. 2016). Initially the business in the poultry market was characterized by high margin and low volume. The competition in the industry has risen in manifolds leading to the low margin and high volume.

"Ecosystem" conveys the idea that all the pieces of an economy come together in particular places, and that their strength and interactions determine prosperity and economic growth. In Silicon Valley there is a sense that you prosper only because you're surrounded by lots of resources that make it possible to succeed, beyond what your own entity controls. We think of it as a garden, where we need fertile soil, seeds, and other ingredients to make things grow (Kanter 2012).

\footnotetext{
*DBA (Doctor of Business Administration) Student, Institute of Business Administration, University of Dhaka

** Associate Professor, Institute of Business Administration, University of Dhaka

${ }^{1}$ http://print.thefinancialexpress-bd.com/2015/08/06/102839. [Accessed 25 November 2016]

${ }^{2}$ The home-town of the first author.

${ }^{3}$ Raha, S. K. is the Professor, Department of Agribusiness and Marketing, Bangladesh Agricultural University, Mymensingh

${ }^{4}$ However, after a certain time, i.e. when a layer stops breeding eggs, the same can be consumed for meat purpose.

${ }^{5}$ The Daily Ittefaq, March 10, 2011
} 
The business ecosystem is referred as a stream of theory in the field of strategic management ( Lengnick-Hall and Wolff 1999). It is believed that business ecosystem is capable of explaining better how the multi-sided business evolve (Eisenmann, Parker, and Van Alstyne 2006; Parker and Van Alstyne 2005).

Moore (1993, tinyurl.com/cygzy60) defines a business ecosystem as consisting of certain layers as shown in Figure No. 1. There are three layers named as: (i) core business, (ii) extended enterprise, (iii) business ecosystem. These layers correspond to different levels of commitment to the business. The core business layer contains the parties which form the heart of business. This layer may be run by a single company or the supply chain may be coordinated by the focal company. In other words, it can also be formed with a number of companies; each company is taking care of the core business. The second layer, extended enterprise, extends the concept of business supply chain and it includes the customers, complementors, second layer suppliers, standard-setting bodies in the respective field of business. The third layer encompasses trade association, unions, universities, research bodies, investors, stakeholders, etc. to define the boundary of business ecosystem. These parties have direct or indirect impact on the success of any business (Rauhala 2012)

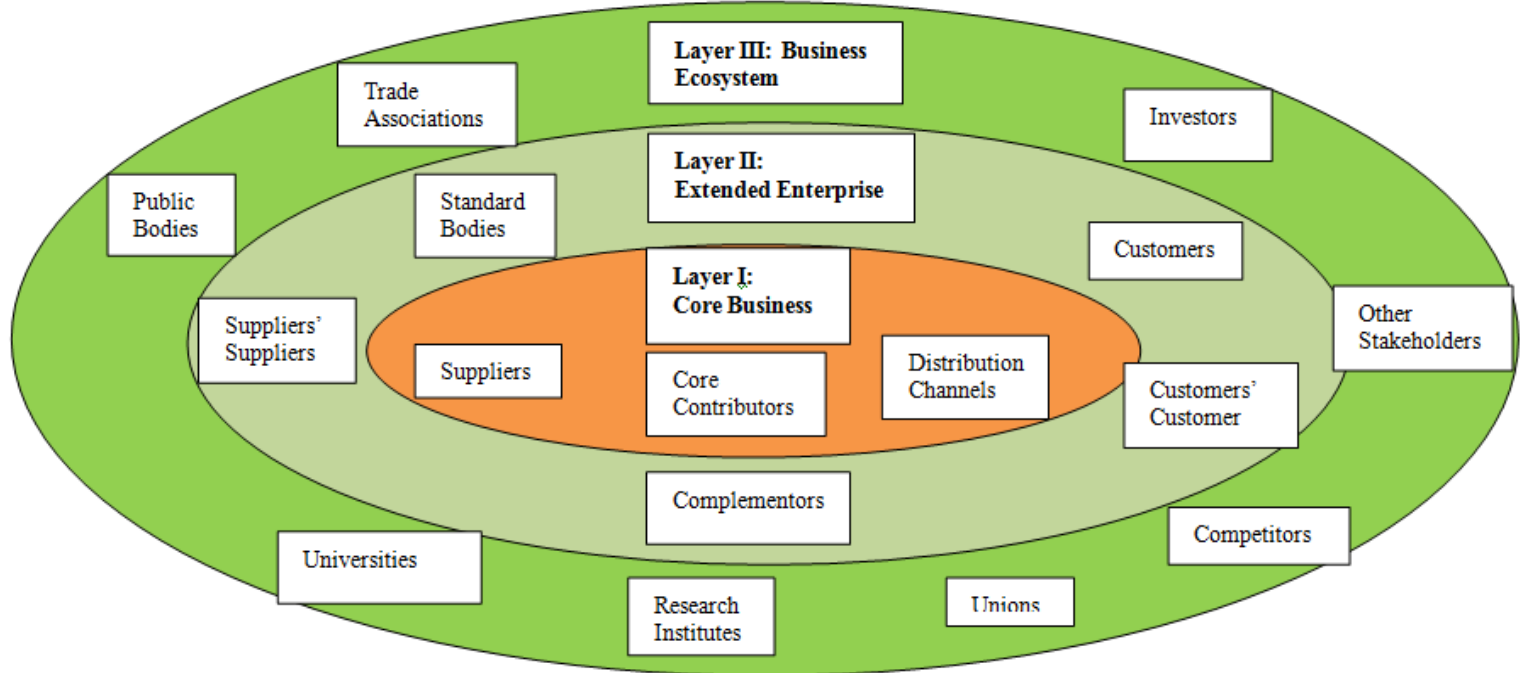

Figure No. 1: Layers of Business Ecosystem Source: Moore (1993, tinyurl.com/cygzy60) ${ }^{6}$

Business ecosystem, according to Businessdictionary. $\mathrm{com}^{7}$, is a strategic planning model, popular since the development of information technology, whereby a network of suppliers, distributors, competitors and customers all work through competition and cooperation to advance sales of products.

Investopedia.com ${ }^{8}$ defines business ecosystem as the network of organizations - including suppliers, distributors, customers, competitors, government agencies and so on - involved in the delivery of a specific product or service through both competition and cooperation. The idea is that each business in the "ecosystem" affects and is affected by the others, creating a constantly evolving relationship in which each business must be flexible and adaptable in order to survive, as in a biological ecosystem.

Now this concept may be related to ecosystem in poultry business in Bangladesh. The first component like suppliers go with the vendors ${ }^{9}$ under poultry population (grand parent stock, parent stock, day-old-chick [DOC], etc.); feed supplier including suppliers of raw materials for producing feeds, additives for feeds; vaccines and/or medicine suppliers; etc. The second component distributors may relate to the distributors in the segment of the output of poultry production namely meat and eggs. An important component here is the waste management for environmental sustainability. The third component customers include both at the institute level hotels, seven star hotels, motels, restaurants, etc. On the other hand, the individual level customers are the ultimate consumers who shop the meat or eggs from the retailers or the company (retail) outlets ${ }^{10}$. The fourth component competitors are the players in the same segment (poultry) and the players in other livestock-items such as duck, pigeon, beef, mutton, fishes, etc. The fifth components are the government agencies including Ministry of Fisheries and Livestock which has eight subordinate offices. The sixth component may fall under academic bodies/institutes which are mostly working under the auspices of government. The seventh component is the availability of financial access, that is, the presence of banking and financial facilities. The eighth component includes associations working in poultry industry. The ninth element relates to consumers as a whole being represented by CAB (Consumers Association of Bangladesh). When all these components together at the effective and efficient level, the industry is expected to perform properly. It may be noted here that the components shown so far under poultry business ecosystem are not the

\footnotetext{
${ }^{6}$ Available at https://timreview.ca/.../HeikkilaKuivaniemi_TIMReview_June2012.pdf

${ }^{7} \mathrm{http}: / /$ www.businessdictionary.com/definition/business-ecosystem.html. [Accessed 25 November 2016].

${ }^{8}$ http://www.investopedia.com/terms/b/business-ecosystem.asp. [Accessed 25 November 2016].

${ }_{9}^{9}$ Vendors and suppliers are used here interchangeably since suppliers in poultry business may go up to the consumers level such as supplying broilers in cut condition or live condition to the individual consumers. It is mentioned that supplier refers to the case of B2B (business to business) and vendor refers to the case of both B2B and B2C (business to consumer).

${ }^{10}$ The outlets of the commercial poultry firms.
}

DOI: $10.9790 / 2380-1002020112 \quad$ www.iosrjournals.org $\quad 2 \mid$ Page


least in number, it may be extended further. The waste management may also work as an integrated element/component in poultry ecosystem.

Based on the components in ecosystem, the actors surrounding poultry business may be classified as market actors and non-market actors. The market actors may cover suppliers, distributors, customers, and competitors. It may be stated here that core value, backward linkages, forward linkages, support system, customer base, etc. work under market actors. On the other hand, education and training facilities, policies, guidelines, legal frameworks, etc. work under non-market actors as facilitators. Specifically, the non-market actors may be outlined as government agencies, academic and training institutes, waste management, banking and financial institutions, $\mathrm{CAB}$, associations in poultry industry, etc.

\subsection{Objectives}

\section{Research Objectives And Approach}

The primary objective of the study is look into poultry industry from the perspective of business ecosystem. This is an initiative to apply a biological concept (developed in 1930s by the British botanist and applied the same in business by the business strategist James Moore in mid 1990s) to the poultry business. The study aims at seeing the interacting, supporting, competing stakeholders playing their respective roles towards the attainment of a basic need (need for nutrition, protein, etc. in the form of meat, eggs, etc. under the broad head of health need) of human kinds. Specifically the study has addressed the following issues:

- Suppliers working from both perspectives: backward linkage and forward linkage.

- Distributors facilitating the flow of both output and input of the industry.

- Customers and consumers buying products of the industry.

- Competitors enriching market intensity.

- Government agencies including academic and training institutions facilitating the industry

- Waste management status for environmental sustainability.

\subsection{Methodologies}

The study is based mainly on secondary data. The data sources include published article and/or journal, newspaper, magazines, websites, etc. The data have also come from the report of relevant agencies such as FAO (Food and Agriculture Organization of the United Nations), IDE (International Development Enterprises), government bodies like Ministry of Fisheries and Livestock and its sub-offices namely Department of Livestock Services, Bangladesh Livestock Research Institute, etc. The data sources also include consultation with some knowledgeable persons in poultry sector.

\subsection{Scope and Limitations}

The study aims at the coverage, as much as possible, of the components as the participants involved in the poultry business ecosystem. It reflects as a picture of listing all the bodies, institutes, etc. working either as contributors or competitors of poultry business under the framework of ecosystem.

It may be thought that the respective field and/or discipline concerned with the topic of the article broadly is agriculture or animal/poultry science. The author's background is in business management and finance. This contradiction may work as a limitation in the study.

\subsection{Rationale of the Study}

So far the literature, information consulted, it was not found the work on poultry industry as presenting under the concept of business ecosystem. Many works have been done on poultry under value chain system, supply chain system, input-output system, etc. But as a business ecosystem, it has been hard to see the poultry industry. In that sense the study carries significance.

\section{Pouultry Business Ecosystem}

Here it is reiterating the definition of ecosystem. The definition, particularly the definition of business ecosystem, stands as the network of suppliers, distributors, customers, competitors, government agencies and so on involved in the delivery of a specific product or service via both competition and cooperation. And all these may be categorized as market actors and non-market actors. In relation to suppliers, the actors may relate to the backward linkage and forward linkage.

\subsection{Market Actors}

\subsubsection{Suppliers: Backward Linkage}

Universally, the starting point in suppliers in regard to poultry starts from pedigree/elite as shown in Figure No. 2. Farms with pedigree/elite, great-grandparent, grandparent birds are considered primary breeder farms, all of which produce eggs for hatching. The progeny of pedigree flocks form great-grandparent flocks, and the progeny of great-grandparent flocks form grandparent flocks, and so on. The progeny of multiplier (i.e. parent) flocks become production birds on broiler (meat production) or layer (table-egg production) farms (thepoultrysite 2016). 


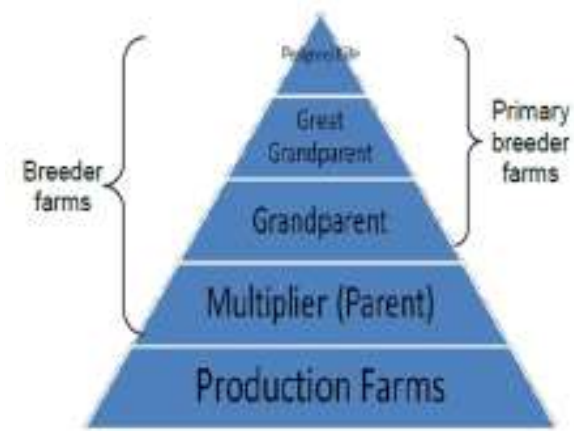

Figure No. 2: Hierarchy in Poultry Generation and/or Progeny Source: thepoultrysite (2016)

In Bangladesh the poultry progeny starts from grandparent stock. The grandparent is reared to produce parent stock. The broiler chicken production process in Bangladesh begins the grandparent breeder flocks. The breeder flocks are raised to maturity in grandparent growing and laying farms where fertile eggs are produced. Grandparent chickens are mostly imported from abroad and reared in Bangladesh. The import sources are USA, UK, Denmark, and France. There are eight grandparent farms in the country (boi 2013) namely: (i) Kazi Farms Limited, (ii) Paragon Poultry Limited, (iii) Quality Feeds Limited, (iv) CP Bangladesh Company Limited, (v) Aftab Bahumukhi Farms Limited, (vi) Agha, (vii) Nourish Poultry Hatchery Limited, and (viii) ACI Godrej Agrovet Limited (boi 2013 and Bodington 2007).

The next supplying point under backward linkage is parent stock farms. Parent breeders are hatched from the fertile eggs from grandparent flocks. After arrival from the hatchery at one day old, these are reared, housed and managed similarly to grandparent flocks. Parent stocks provide eggs to hatch final broiler or layer to breed. Raha (n.d.) states there are 82 parent stock farms operating and producing 5.5 million to 6.0 million DOCs of broiler and 0.5 million layer DOCs per week.

The next supplying category includes broiler farms. The broilers are reared in farms for meat production. They typically weigh about $1.2 \mathrm{Kg}$ to $1.5^{11} \mathrm{Kg}$ at the time of slaughter. After rearing, broilers move as live birds either to processing plants or consumers through intermediaries. The average price per Kg of broiler is BDT 119.00 at farm level, the same is BDT 123.00 at wholesale level and BDT 184.00 at retail level (boi 2013).

Another supplying component under backward linkage is poultry feeds. There are 50 to 60 poultry feed mills in the country (Probenewsmagazine 2011). The price ups and downs of chicken are directly related to the rise and fall of prices of feeds. About 70 percent of a poultry farm's expenditure is for feed. Major raw materials of poultry feed are maize/corn, soybean. Only 50 percent of the demand for corn/maize is met locally (Dolberg 2008); the rest is imported from abroad including Brazil, USA, Ukraine, India. The other component of poultry feed is soybean meal which comprises the protein portion of feed. ${ }^{12}$ The only 10 percent of soybean-consumption is met locally and the rest is imported (Probenewsmagazine 2011). In Bangladesh soybean was first introduced in 1942 (Yamazaki 2003).

The next component in the backward chain of poultry business value chain is the medicine and/or vaccination suppliers. It also includes the feed additive suppliers. The poultry health related products category here may include nutritional and non-nutritional feed additive/supplement, water soluble nutrition, bio-security, therapeutic drugs, vaccines (eongroup 2016). Animal health product means and includes any substance intend for preventing, destroying or controlling any disease in animals, or help in the general health and productivity improvement of the animal or farm. It shall also refer to nutritional substances which improves the performance, feed utilization, and general condition improvement of farm and companion animals (Membership Directory $2013^{13}$ ). In Bangladesh the majority of multinational corporations access the market through distributors that then either sell directly to the end users or sell through another sub-distributors or local agents. Traditionally, pharmaceutical and feed additive companies support distributors through product training, production technology and marketing support.There are more than 100 pharmaceutical companies in operation in Bangladesh (boi 2013). The overall status in poultry medicine, vaccination, feed additive is that the market is primarily serviced by local companies acting either as primary manufacturers themselves or as distributors of multinational companies (Bodington 2007).

\subsubsection{Suppliers: Forward Linkage}

After the backward linkage in the ecosystem, the place of forward linkage comes to the picture which is also known output industry. The output industry may be divided into two parts: (i) meat, and (ii) eggs. The first part, i.e. meat may also be further divided into two parts: (i) live meat sold as live broiler ${ }^{14}$, (ii) cut meat used for further processed food items.

The most common links through which the poultry output, meat and eggs, go through are shown below based on the results of a survey made on 450 broiler farms reported by Shah et al. (2006).

\footnotetext{
${ }^{11}$ In Bangladesh it is the standard as stated at www.boi.gov.bd.

${ }^{12}$ Also cited from depth interview/discussion with the feed suppliers.

${ }^{13}$ Membership Dircectory of AHKAB (Animal Health Companies Association of Bangladesh), 4th Edition, 2013.

${ }^{14}$ Live chicken sold in the market for meat purpose.

DOI: $10.9790 / 2380-1002020112 \quad$ www.iosrjournals.org $\quad 4 \mid$ Page
}




\begin{tabular}{|l|c|}
\hline Marketing Channels & $\mathbf{\%}$ \\
\hline Farm $\rightarrow$ Consumer & 2 \\
\hline Farm $\rightarrow$ Broker $\rightarrow$ Institutional Buyer & 6 \\
\hline Farm $\rightarrow$ Middleman $\rightarrow$ Wholesaler $\rightarrow$ Retailer $\rightarrow$ Consumer & 61 \\
\hline Farm $\rightarrow$ Middleman $\rightarrow$ Wholesaler $\rightarrow$ Middleman $\rightarrow$ Consumer & 31 \\
\hline Total Number of Farmers & $\mathbf{1 0 0}$ \\
\hline
\end{tabular}

Table No. 1: Commercial Value Chain

Source: Dolberg, Frands (2008). Poultry Sector Country Review. Food and Agriculture Organization of the United Nations (FAO)

In regard to price of meat and eggs, the USAID-ATDP II (2005) found a lack of price monitoring. However, retail prices are now provided on the internet by the Department of Agricultural Marketing (DAM) and the Trading Corporation of Bangladesh (TCB). For instance, the day on which this article is being written (17/11/2016), TCB shows on its website the latest price of Broiler Meat per Kg as BDT 130.00 to BDT 140.00 and the same of Eggs (Farm) on the same date as BDT 30.00 to $34.00^{15}$ per hali ${ }^{16}$. The finding is that the price of shown on the DAM's website is more detailed.

It may be reiterated here that the value chain shown above basically is almost the same for live chicken (broiler) and eggs. The value chain for processing and/or processed poultry looks different. Now-a-days this market has been a growing market due to the growing busy middle class consumers. At the present time, through most of the super shops in capital city and other metropolitan city, a big sale takes place against the processed chicken. Generally, the other third party ${ }^{17}$ or the poultry farm supply in the processed or dressed condition or cut condition to the superstores (super shops) and the general consumers purchase the processed chicken from there.

Another feature of processing poultry is that a large portion is sold to the consumers from the retailers located in the wet market. Here the live poultry are slaughtered and dressed in front of the consumers. In this modality, the chickens are sold either directly to the retailer or via distributors that sell to the retail shops who then sell to the end-users. The next form of processed chicken meat market is the existence of the outlets of commercial poultry farms and other group of companies from where fried chicken are sold to the consumers. The examples are the outlets of CP Bangladesh, Kazi Farms, etc. Others are KFC (Kentucky Fried Chicken) ${ }^{18}$, BFC (Best Fried Chicken), CFC (California Fried Chicken), Pizza Hut, etc. Other branded conglomerates such as Aftab, Pran, Abdul Momen Ltd. are also coming to this market. This is the market of BDT 1.50 billion (Daily Star 2015). The names of the food items in this market are Nugget, Sausage, Drumstick, Burger Patty, Wings, Chicken Ball, etc.

\subsubsection{Distributors}

Distribution includes activities, costs, and assets dealing with physically distributing the product to buyers. Broadly it also covers finished goods warehousing, order processing, order picking and packing, shipping, delivery vehicle operations, establishing and maintaining a network of dealers and distributors. Distribution aims at improvements with respect to forward or downstream portion of the value chain system (Thomson et. al. 2012).

In the poultry industry in Bangladesh, distributors ${ }^{19}$ take place in both segments: backward linkage and forward linkage. In the backward linkage, distributors' position is mostly in the supply of feeds and DOCs. The grower enjoys credit from the dealer until the birds are marketed to the retailer via a paiker. The money received for the mature chickens is returned to the commercial grower usually after the cost of the feed has been deducted from the grower's payment by the paiker and paid to the dealer. The dealer here works as a third party facilitator towards the feed company and DOC supplier. The DOC suppliers sell their chicks through dealers and allow the dealer commission (Boddington 2007). This is how, the dealers' role runs in the case of feed and DOC.

In the case of supplying medicines, vaccinations, and feed additives; the distributors' position is in between pharmaceutical companies and the poultry farmers. Boddington (2007) states that here pharmaceutical companies mostly enter into the market either selling directly to the end users or through distributors /sub-distributors or local agent.

In summary, the formal place of distributors is mostly in backward linkage areas such as DOCs, feeds, feed additives, vaccines, etc. The place of the same in forward linkage areas such as broilers, eggs, processed chicken is mostly in value chain format. For instance, live broilers, eggs move via paiker to wholesaler to retailer to consumer. The processed chicken moves via fast food outlets, superstores, commercial poultry farms' own integrated channel, etc.

\subsubsection{Customers}

The customer base of poultry may be classified into two groups. One is the institutional group consisting of restaurants, fast-food chains, and hotels (boi 2013). And the other one is the individual group consisting of consumers. Customers are important for any business to be successful. Over 50 years ago, Peter Drucker observed that a company's first task is "to create customers" (Kotler 2001). Customers are important intangible assets of a firm that should be valued and managed (Gupta, Sunil and Lehman 2003).

\footnotetext{
${ }^{15} \mathrm{http}: / /$ www.tcb.gov.bd/site/page/fc280846-de46-47f0-a722798971182926/\%E0\%A6\%B8\%E0\%A6\%B0\%E0\%A7\%8D\%E0\%A6\%AC\%E0\%A6\%B6\%E0\%A7\%87\%E0\%A6\%B7$\% \mathrm{E} 0 \% \mathrm{~A} 6 \% \mathrm{AC} \% \mathrm{E} 0 \% \mathrm{~A} 6 \% \mathrm{BE} \% \mathrm{E} 0 \% \mathrm{~A} 6 \% 9 \mathrm{C} \% \mathrm{E} 0 \% \mathrm{~A} 6 \% \mathrm{BE} \% \mathrm{E} 0 \% \mathrm{~A} 6 \% \mathrm{~B} 0-\% \mathrm{E} 0 \% \mathrm{~A} 6 \% \mathrm{~A} 6 \% \mathrm{E} 0 \% \mathrm{~A} 6 \% \mathrm{~B} 0$. [Accessed 18 November 2016]. ${ }^{16}$ Consisting of four (4) items.

${ }^{17}$ They don't have any farm, they procure birds from the small farmers or the commercial poultry farm and slaughter as well as dress at their own plant (slaughtering house) and supply to the superstores such as Meena Bazar, Agora, Shapno, etc.

${ }^{18}$ Kentucky Fried Chicken, since 2006 it was running as Franchisee under Transcom Foods Ltd., a business unit of Transcom Group. KFC is a subsidiary of Yum! Brand, an American fast food company.

${ }^{19}$ They are generally treated as dealers. 
Similarly in relation to poultry business customers are important assets. As an interacting component under ecosystem of poultry business, customers also play a role in the market. But this role play is not significant and organized. Because here (in Bangladesh) traditionally the customers are not associated and organized as like as other associations like breeders association, eggs association, poultry association, etc. ${ }^{20}$ An association named Consumer Association of Bangladesh $(\mathrm{CAB})$ works here. But its functioning appears to be restricted to issuing periodic assessments reports on the price situation and costs of living (The Independent 2015). And in relation to poultry consumption the voice of CAB is not found remarkably in the secondary information.

\subsubsection{Competitors:}

The competition, another component in business ecosystem, may be applied to the poultry industry with the help of Five Forces Model (Porter 1979, 2008 cited from Ali and Hossain, 2016) as shown in the figure No. 3. Industry Competitors include both the domestic farms and foreign farms. The domestic farms may refer to large as well as small farms. Some of the names of the large scale domestic poultry farms are Kazi Farms Limited, Paragon Poultry Limited, Quality Feeds Limited, CP Bangladesh Company Limited, Aftab Bahumukhi Farms Limited, Nourish Poultry Hatchery Limited, ACI Godrej Agrovet Limited, etc. As on February 2013, there were 65,902 poultry farms in the country (Raha n.d.). Boi.gov.bd (2013) states there were 110,000 poultry farms in the country. There are leading seven foreign companies working in the market out of which five from India and one (C.P. Bangladesh Co. Ltd.) from Thailand; another (New Hope Feed Mill Bangladesh Ltd.) is from China (globalmeatnews.com 2016).

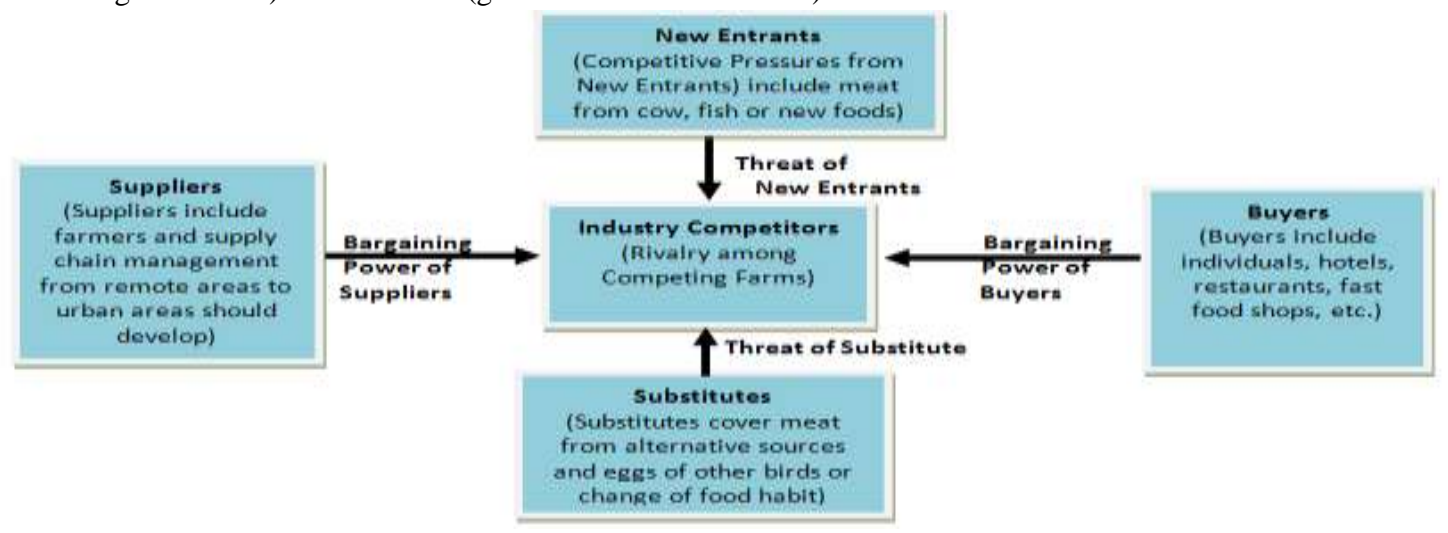

Figure No. 3: Application of Five Force's Model to the Competition in Poultry Industry Source: Ali and Hossain, 2016

New Entrants to a market may bring new production capacity, the desire to establish a secure place in the market, and sometimes substantial resources (Thomson et. al. 2012). New entrants are adding to both the backward linkage such as feeds, vaccination, DOC supply as well as to the forward linkage such as dressed or processed chicken, chicken-based readyto-cook products, etc. The large scale farms such as Aftab Bahumukhi Farms, CP Bangladesh and Kazi Farms, Paragon, have started commercial marketing for eggs, dressed/ processed chicken, and chicken-based ready-to-cook items that are produced in their own farm. This has increased the number of new entrants in the output market (forward linkage market). Another example is that in the frozen snacks and fried chicken segments new entrants are coming such as Abdul Monem Ltd., Pran-RFL, etc. (The Daily Star 2015). On the other hand, in the backward linkage, over the time the players from both foreign investors (foreign poultry farms) and local farms including small entrepreneurs have added to the existing market. Through import, the number of new entrants is also increasing. For instance, Provita Feed and Hatchery Limited, a large poultry feed supplier at the national level. Earlier this company generally procured maize locally ${ }^{21}$. Maize is one of the major raw materials of poultry feeds. Now this farm is importing from abroad. As a result a new entrant has taken place in the market of maize supply via import.

Companies in one industry may come under competitive pressure from the actions of companies in a closely adjoining industry whenever buyers view the products of the two industries as good substitutes (Thomson et. al. 2012). The substitute items of poultry chicken may include ducks, pigeons, migratory and wild birds ${ }^{22}$. Other substitutes may include cattle, buffalo, goat, sheep, etc. The eggs and chicken meat also work as the substitute of each other.

Whether the suppliers of industry members represent a weak or strong competitive force depends on the degree to which suppliers have sufficient bargaining power to influence the terms and conditions of supply in their favor (Thomson et. al. 2012). In the case of commercial poultry market, the eight grandparent poultry suppliers may have a role in influencing on the price of broiler. Their regular supply of DOCs hampers that impact on the market price of broiler, eggs, etc. On the other hand, the grandparent suppliers are also dependent on the supply of quality feed supply, vaccination, etc.

Whether buyers are able to exert strong competitive pressures on industry members depends on (i) the degree to which buyers have bargaining power, and (ii) the extent to which buyers are price-sensitive.

\footnotetext{
${ }^{20}$ Though these associations' role is not satisfactory as found from relevant studies.
}

${ }^{21}$ The author had a relationship with Provita Feed and Hatchery Limited via official dealings.

${ }^{22}$ However, these birds are prohibited to be preyed as per law of the country.

DOI: $10.9790 / 2380-1002020112 \quad$ www.iosrjournals.org $\quad 6 \mid$ Page


The buyers' bargaining power here in the poultry market is insignificant as reflected earlier under the section of customers. Here price is generally dominated by the poultry suppliers, particularly large commercial farms. However, there is the competition among the commercial poultry farms. But the voice of consumers, especially the individual consumers' voices are not influential. Their voices are not echoed to influence the price structure of poultry items such as eggs, meat, live broiler, etc. (Thomson et. al. 2012). The voice of Consumers Association of Bangladesh (CAB) is not in the line to be referred.

\subsection{Non-Market Actors: Facilitating Agencies}

The market actors include core value, backward linkages, forward linkages, support system, customer base, etc which have been addressed. On the other hand, the non-market actors covering education and training facilities, policies, guidelines, legal frameworks, etc. that may be addressed in this section.

\subsubsection{Ministry of Fisheries and Livestock (MFL)}

The prime non-market actor working as facilitator is the Ministry of Fisheries and Livestock. The ministry is mandated to discharge certain functions for the overall development of livestock and fisheries ${ }^{23}$ (mof.gov.bd. 2016). Poultry is one of the segments under livestock sector. The overall functions of the ministry also go to poultry industry. However the major functions of the ministry are to : (i) formulate, upgrade, and implement laws and policies relating to the fisheries and livestock sector; (ii) develop different varieties of fish, livestock and poultry, as well as prevent and control diseases; (iii) conduct research and training programs related to fisheries and livestock resources; (iv) improve livestock nutrition and insemination; (v) survey fisheries, animal resources, and matters related to zoos; (vi) develop, extract, conserve, and manage marine fisheries; (vii) develop dairy, cattle, and poultry farms and control quality; (viii) increase production of fish, meat, milk, and eggs to achieve self sufficiency in protein (mof.gov.bd. 2016).

With other policies, the ministry has also promulgated National Poultry Development Policy 2008. The ministry has eight subordinate offices (GOB 2016). The offices are (i) Department of Livestock Services, (ii) Department of Fisheries, (iii) Bangladesh Livestock Research Institute (BLRI), (iv) Bangladesh Fisheries Research Institute (BFRI), (v) Fisheries and Livestock Information Service, (vi) Bangladesh Fisheries Development (vii) Marine Fisheries Academy, (viii) Bangladesh Veterinary Council.

The ministry provides training on efficient and improved farm management systems through Department of Livestock Services. It has set three priority areas based on government development expenditure in the livestock and fisheries sectors. In this priority ranking poultry industry has been set as the third prioritized sector.

In brief, the ministry's work may be summed up as (i) overall major functions for the development of livestock and fisheries, (ii) maintaining as many as eight sub-offices, (iii) promulgating different policies and acts including National Poultry Development Policy 2008 and National Livestock Development Policy 2008, (iv) awareness activities on livestock and poultry diseases including Avian Influenza, (v) rehabilitation program, etc.

\subsubsection{Department of Livestock Services (DLS)}

This is a sub-office of the Ministry of Fisheries and Livestock. The office is headed by a Director General (DG) who is aided by a group of professionals and supporting staff (about 8,426 at present ${ }^{24}$ ). The department has two veterinary colleges, located in Chittagong and Sylhet, and is planning to establish two more in Barisal and Dinajpur ${ }^{25}$. In addition, in collaboration with Bangladesh Livestock Research Institute, Bangladesh Agricultural University, and other research organizations, the Department is trying to develop and propagate sustainable technologies to accelerate the developments in respect of livestock and poultry (banglapedia 2016).

The department has promulgated 14 policies, rules in different times including some are before independence of the country. And out of these 14 promulgations, the most relevant with the study is the National Poultry Development Policy - 2008. In short, the Department of Livestock Services is working as an arm of the government for the development of poultry sector.

\subsubsection{Bangladesh Livestock Research Institute (BLRI)}

Bangladesh Livestock Research Institute (BLRI) conducts research activities for the development and improvement of the livestock sector including poultry industry (banglapedia 2016). It was set up by JAICA (Japan International Cooperation Agency). The office is headed by a DG. The present incumbent is the first woman DG of BLRI under National Agricultural Research System (NARS) (blri 2016). mandates.

As the name implies the institute is engaged in conducting researches in livestock with certain general and specific

There are eight research divisions in BLRI namely (i) animal production, (ii) poultry production, (iii) animal health, (iv) goat and sheep production, (v) biotechnology, (vi) socio-economics, (vii) system research (on-farm research), (viii) training, planning, and technology testing.

In poultry, it is working for conserving, improving, and maintaining both hybrid chicken as well as native chicken including poultry feed analysis. For instance, in 2013-14 its reaserch outputs were Shuvra (BLRI Layer 1), Shorna (BLRI Layer 2) in hybrid chicken; 273 feed analyses. In short this institute as a facilitator is conducting research works to boost further the development of poultry sector (blri 2016).

\subsubsection{Fisheries and Livestock Information Service (FLIS)}

Fisheries and Livestock Information Service started its journey in 1986 with a pool of human resources against 110 posts. FLIS is working for generating awareness among the stakeholder about the information related to poultry as well as

\footnotetext{
${ }^{23}$ www.mof.gov.bd/.../28\%20Chapter\%2030 44 Ministry\%20of\%20Fisheries English.pdf. [Accessed 29 November 2016]

24 en.banglapedia.org/index.php?...Department_of_Livestock_Services -

${ }^{25}$ Now these have been universities which are mentioned under the heading of Academic and training stated later.

DOI: $10.9790 / 2380-1002020112 \quad$ www.iosrjournals.org $7 \mid$ Page
}


livestock development in the country. It is considered as the store house of information regarding livestock and poultry (GOB, flid 2016).

\subsubsection{Academic and Training Institutes}

Some institutes from academic arena are also working for the development of poultry industry in the country. These institutes are mostly at university level and one is at college level namely: (i) 1. Bangladesh Agriculture University, Mymensing; (ii) Sher-e-Bangla Agriculture University, Dhaka; (iii) Bangabandhu Sheikh Mujibur Rahman Agricultural University, Gazipur; (iv) Chittagong Veterinary \& Animal Science University (CVASU), Chittagong; (v) Hajee Mohammad Danesh Science and Technology University, Dinajpur; (vi) Jhenidah Govt. Veterinary College, Jhenidah; (vii) Patuakhali Science and Technology University, Patuakhali (viii) Sheikh Fazilatunnesa Mujib Fisheries College, Mymensingh; (ix) Sylhet Agricultural University, Sylhet.

Among the above universities, the Bangladesh Agricultural University (BAU) enjoys the highest profile (Boddington 2007). Boddington conducted a study based on BAU and CVASU. In regard to findings he states that there is a trend for the government to reduce the number of graduates they employ and thus more will enter the private sector. It is important to increase the exposure of students to real life experiences in industry and to involve industry in the direction of research and education which has also come out from the discussion/in depth interview with the market players in the industry ${ }^{26}$.

The course curricula includes broiler, layer and breeding flocks management, poultry housing, environment and welfare issues, poultry nutrition, disease prevention, hatchery operation and processing, marketing distribution of poultry and poultry products. The courses and/studies at Undergraduate, Graduate, and $\mathrm{PhD}$ level offer both theoretical and practical knowledge and experiences (sau 2016).

\subsubsection{Business Associations}

Boddinton (2007) states poultry industry has as many as five association namely: (i) World Poultry Science Association (WPSA), (ii) Animal Health Association of Bangladesh (AHCAB), (iii) Bangladesh Poultry Breeders Association, (iv) Bangladesh Feed Association, and (v) Bangladesh Egg Producers Association. Out of these five associations, all are mainly involved functionally in networking and lobbying except WPSA which involves in global poultry research. Bangladesh Poultry Directory (2013) added another three associations named (i) Bangladesh Poultry industries Association, (ii) BCS Livestock Association, and (iii) Bangladesh Poultry Welfare Association resulting into eight associations in total. As per the directory, beside these associations, there are also local associations (such as Khulna Poultry and Fish Feed Shop Owners Association) and related associations (such as Bangladesh Veterinary Association, Bangladesh Veterinary Council, Bangladesh Fancy Pigeon Breeders Association, etc.) in the country.

The effectiveness of the associations is mixed. Boddington (2007) states that the associations are in many cases engaged in self-serving and in particular seen to favor those involved at the most senior level. Boddington further added that no one mentioned that associations could play a role in increasing poultry consumption whereas globally associations drive for promoting and creating awareness for increasing demand for their produce.

\subsubsection{Banking and/or Financing}

Traditionally the financial stakeholder of poultry industry in Bangladesh is the Krishi Bank named as Bangladesh Krishi Bank. However other commercial banks and NBFIs (Non Bank Financial Institutions) also provide financial facilities to the agro-based industry including poultry sector. They provide it (financing facility) under the coverage of SME (Small and Medium Enterprises) scheme or under the bank's/NBFI's own program/scheme. There are 64 commercial banks (including two specialized banks, nine foreign commercial banks, four non-scheduled banks) and 31 NBFIs (Non-Bank Financial Institutions) in the country at present (Bangladesh Bank Website 2016).

The important news in this regard is that there some poultry commercial farms at MNC level as mentioned earlier. They may avail finance from global banks like SCB (Standard Chartered Bank), HSBC (Hong Kong Shanghai Banking Corporation) or from their home country's bank at a lower rate of 4 to 5 per cent (Financial Express 2012). Their investments here are massive in comparison with the local companies. These companies bring in medicines, feed and other finished products at cheap prices and from their respective countries (probenewsmagazine 2011). The financing modality best suits with poultry business relates to the kind of facilities like CC (Cash Credit), OD (Overdraft), Term Loan, Lease, Revolving, etc. The significant characteristic of the facility suitable to poultry industry is trade credit in nature.

\section{Poultry Waste Management: Environmental Concern}

$70 \%$ of a poultry (chicken) body is edible. The waste items of a poultry farm includes litters from broilers, layers, hatchery-debris, dead birds, feathers, etc. Poultry litter is widely used as fertilizers, livestock feed (however it is not encouraged) and in some case as fuel to the electricity generating plants. Feathers are used in many products such as pillows, dust cleaners, costume accessories, etc. A poultry waste rendering plant converts all the non-edible poultry waste parts into a sterilized meat meal which is used in the formulation of animal feed. For instance, in the USA it is used as a low-cost meat for dog-food, cat-food, etc. The estimated cost of equipment, building and land development for a poultry waste rendering plant is BDT 10,400,000.00 for a plant capacity of 1000 birds per day (boi 2013).

Saker et al. (2009) conducted a survey in Kishoregonj, Mymensingh, and Gazipur districts to identify the poultry waste materials and to see the disposal procedure of waste. The survey was carried out in 10 small, 6 medium, and 4 large scale farms. The study listed litters, manures, odors, noise, feathers, dust and chemicals, wastewater, insects, dead birds, hatchery debris and dust from feed manufacturing plants as the poultry waste items. The study states that litter generally consists of a mixture of manure, bedding materials, wasted feed, feathers and some portion of soil. The study found that

\footnotetext{
${ }^{26}$ During writing this article the author talked with some businessmen involved directly in pultry industry particularly in supplying feed items such as maize, soybean, MBM (Meat Bon Meals), etc.

DOI: $10.9790 / 2380-1002020112 \quad$ www.iosrjournals.org 8 Page
}


Among the small farm owners $20 \%$ farmers could not use their poultry litter for any particular work, $40 \%$ of them sold their poultry litter in the market, $30 \%$ of them used their poultry litter for crop production and, $10 \%$ of them used their poultry litter for fish culture. About $50 \%$ of the medium farm owners used their litter for fish culture and all the large farm owners sold their litter after a particular time. It was observed that litter contained a high amount of nitrogenous substances (crude protein $24.9 \%$ ) and ash $24.7 \%$ and total digestive nutrients $50 \%$. Litter can be processed following deep stacking, composting and in lagoons, which were available in the study area.

\section{In-Depth Interview: The Issues Commonly Echoed}

Five companies were interviewed in-depth. Four of them are located in Dhaka and one is in Manikgonj. They are the direct suppliers to the feed millers. The brief of the companies is in the appendix. The companies are: (i) Shahparan Agro Industries Limited (referred as "Shahparan"), (ii) Hoque Corporation, (iii) Union Agrovet Limited (referred as "Union Agrovet"), (iv) Trust Enterprise, (v) M/s Mahade Traders (Mahade Traders). Commonly they mentioned some issues as the key factors of the industry at the present time. These are:

- The first factor is the high competition in the market. Both the big players and the mid-players are importing the main component of the poultry feed (maize) in bulk quantity. Around 60 percent of raw materials used in poultry feed is maize. The importing sources are Brazil, Ukraine, USA, Australia, India. Banks are now more flexibly funding the traders, feed millers than the earlier time. Because banks are now on excessive liquidity money. Financing is not working as so hurdle now-a-days.

- Due to available import in the market, there are no words like as "off season", "peak season" in terms of price as earlier time. Round the year, raw materials are available in the market and price remains more or less stable between BDT 15 to BDT 20 Per Kg. Back to three (3) to four (4) years, the price sometimes went up to around BDT 30 Per Kg. This stable price has contributed to the consumer level price against the output: meat and/or broiler, egg.

- The big players are becoming bigger. They are dominating market based on their strength in finance, technology, integrated facility, product portfolio, etc. Sometimes, they also try to influence the regulators, facilitators to control the market. Earlier they tried to make a bar through DLS on producing feeds from the rented plants. Generally the rented plants are used by the mid or small scale feed millers. However, they didn't become successful in this mission. Because government intends to boost the small and medium scale industries in the country.

- Foreign companies are also a factor in the market. Some companies' position is so big and influential that they can change market price any time. For instance, $\mathrm{CP}$ is so gigantic that if it stops its continuous supply any time, the price of DOC, broiler, eggs will go up significantly as was narrated by the owner of Trust Enterprise.

- The comments on the role of the facilitator like DLRI, DLS is neutral. However, there is the scope of enlarging and extending their facility to the greater scale towards the door of the farmer, miller, market, etc.

- The view towards the academic institutes like agriculture and veterinary universities and colleges is positive. More professional graduates in the respective fields are coming to the industry. Mentionable that once upon a time, this industry was pioneered and initiated by the non-professional people in a piece-meal way.

- A significant feature of this market is that profit margin has dwindled significantly. Now the market is shaped by "high volume, low margin". Per Kg Net Profit remains around BDT 0.20 (i.e. twenty paisa Per Kg.)

- Associations' role is not as per desire. Most of positions, specially the senior positions, in the associations are dominated and occupied by the large poultry farms. And their activities through associations move towards the interest mostly of the companies they represent.

The overall comments of the companies interviewed may be depicted in summarized form in the Figure No. 4:

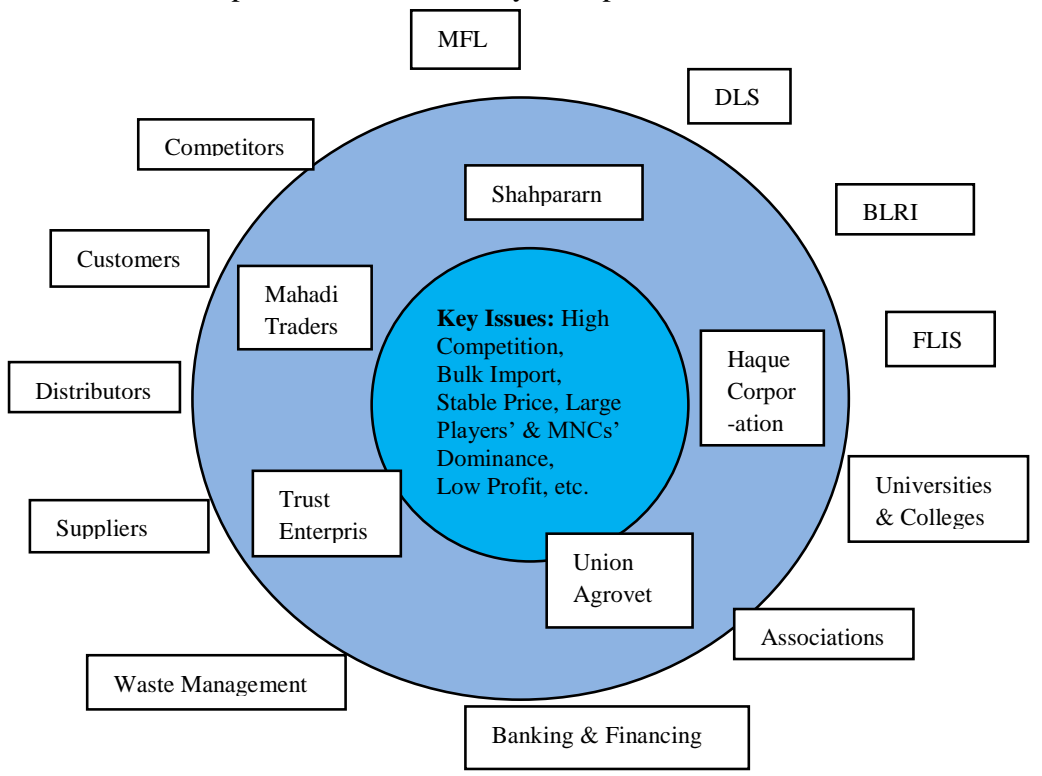

Figure No. 4: Poultry Eco System in Interview Results Source: In-Depth Interview Conducted 


\section{Conclusion}

As like as any other business, poultry business is also working with the help of suppliers, distributors, customers, competitors, government agencies and/or facilitators. In the paper, an effort has been given to look the sector, poultry industry, from a new perspective termed business ecosystem. The word was first coined by British botanist Arthur Tansley in 1930s to refer to a localized community of living organisms interacting with each other. Later in 1993 the business strategist James Moore imported the concept to the increasingly dynamic and interconnected world of commerce through his article in Harvard Business Review mentioning that Successful businesses are those that evolve rapidly and effectively. He noted that in a business ecosystem, companies co-evolve capabilities around a new innovation: they work cooperatively and competitively to support new products, satisfy customer needs, and eventually incorporate the next round of innovations (deloitte.com 2016). Like species in biological ecosystems, firms interact with one another in complex ways, and the health and performance of each firm is dependent upon the health and performance of the whole (keystonestrategy.com 2016).

In the article it has been tried to state how every stakeholder ${ }^{27}$ such as supplier, distributor, customer, competitor, government agency is working, interacting, competing, and supporting individually as well as jointly or in together to provide a complete product or service for selling to the end-users or consumers to make a profit and sustainable growth. The study has striven to put all the parties involved in the poultry business ecosystem in one place. It may be mentioned that the components working as the member of the poultry business ecosystem may be further extended and detailed as more study in future. At the moment, the components stated as participants and/or member of the same (poultry business ecosystem) may be put down in response to the basic model of business ecosystem given by Moore (1993) as depicted below:

\begin{tabular}{|c|c|c|}
\hline Layer I: Core Business & Layer II: Extended Enterprise & Layer III: Business Ecosystem \\
\hline $\begin{array}{l}\text { Suppliers: Suppliers of } \\
\text { both backward and } \\
\text { forward linkage. } \\
\text { Core Contributors: } \\
\text { The poultry } \\
\text { entrepreneurs developed } \\
\text { particularly since } 1990 \text {. } \\
\text { Distribution Channels: } \\
\text { Distributors also } \\
\text { participating in } \\
\text { backward linkage and } \\
\text { forward linkage. }\end{array}$ & $\begin{array}{l}\text { Customers: Both the } \\
\text { institutional and Individual. } \\
\text { Customers' Customer: Feeds' } \\
\text { raw materials' suppliers' } \\
\text { eustomers are the feed millers } \\
\text { and feed millers' eustomers are } \\
\text { the poultry farmers. } \\
\text { Complementors: } \\
\text { Pharmaceutieal companies } \\
\text { supplying the feed additives. } \\
\text { Suppliers' Suppliers: Feed's } \\
\text { raw materials' (such as maize's) } \\
\text { suppliers to the feed millers are } \\
\text { the traders and traders suppliers } \\
\text { are the maize farmers or } \\
\text { exporters. } \\
\text { Standard Bodies: Department } \\
\text { of Livestock Services and other } \\
\text { bodies concerned. }\end{array}$ & $\begin{array}{l}\text { Investors: Domestic as well } \\
\text { as foreign companies } \\
\text { investing in the market. } \\
\text { Other Stakeholders: } \\
\text { Banking and/orFinancing, } \\
\text { CAB (Consumer Association } \\
\text { of Bangladesh), Poultry } \\
\text { Waste Management. } \\
\text { Competitors: Applied } \\
\text { through Porter's five forces } \\
\text { model. } \\
\text { Unions and/or Trade } \\
\text { Associations: As many as } \\
\text { eight (O8) associations in } \\
\text { total. } \\
\text { Research Institutes: } \\
\text { Bangladesh Livestock } \\
\text { Research Institute } \\
\text { Universities: Nine } \\
\text { public/government } \\
\text { universities and colleges. } \\
\text { Public Bodies: Ministry of } \\
\text { Fisheries and Livestock, } \\
\text { Departmentof Livestock } \\
\text { Services, Fisheries and } \\
\text { Livestock Information } \\
\text { Services. }\end{array}$ \\
\hline
\end{tabular}

Figure No 5: Substituting Poultry Business Ecosystem Components Source: The Author(s)

Appendix A

Companies Interviewed: In-Depth Interview

[Brief of the Companies]

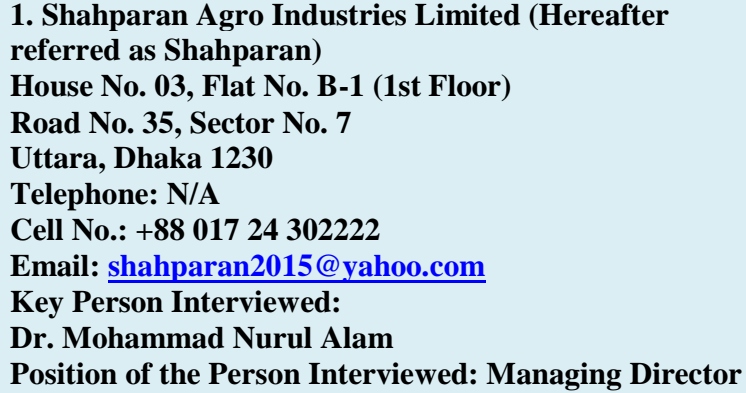

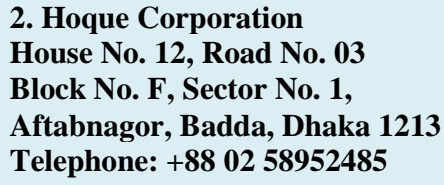

${ }^{27}$ In the paper, the parts of poultry ecosystem have been named as component.

DOI: $10.9790 / 2380-1002020112 \quad$ www.iosrjournals.org $\quad 10 \mid$ Page


1. Shahparan Agro Industries Limited (Hereafter referred as Shahparan)

House No. 03, Flat No. B-1 (1st Floor)

Road No. 35, Sector No. 7

Uttara, Dhaka 1230

Telephone: N/A

Cell No.: +88 01724302222

Email: shahparan2015@yahoo.com

Key Person Interviewed:

Dr. Mohammad Nurul Alam

Position of the Person Interviewed: Managing Director

\section{Union Agrovet Limited}

(Hereafter referred as Union Agrovet)

Suite No. 9/03 (9th Floor)

Eastern Mansion, 67/9 Kakrail

Dhaka - 1000, Bangladesh

Telephone: +88029333938

Cell: +8801711597373

Email: kazal@unionagrovet.com.bd

Website: www.unionagrovet.com.bd

Key Person Interviewed:

Md. Asraful Alam Kazal

Position of the Person Interviewed:

Managing Director

\section{Hoque Corporation}

House No. 12, Road No. 03

Block No. F, Sector No. 1,

Aftabnagor, Badda, Dhaka 1213

Telephone: +880258952485

Cell No.: +88017 $72984331,+8801842900121$

Email: hoquecorporation@gmail.com; mizan@aaebd.com

Key Person Interviewed:

Md. Mizanul Hoque

Position of the Person Interviewed: Managing Director

\section{M/s Mahade Traders (Mahade Traders)}

Bangladesh Hat, Gorpara, Manikgonj

Cell Phone: +88 01752 548807, +88 01824567124

Key Person Interviewed: Md. Rofiqul Islam (Dorbesh)

Position of the Person Interviewed: Proprietor

\section{References}

[1]. Alders, R. G. and Pym, R. A. E. (2009). Village Poultry: Still Important to Millions Eight Thousand Years after Domestication. World's Poultry Science Journal. 65: 29-35.

[2]. Ali, Muhammad Mahboob, Hossain, Md. Moulude (2016) "Problems and Prospects of Poultry Industry in Bangladesh: An Analysis". Available at http://bea-bd.org/site/images/pdf/15.pdf . [Accessed 05 October 2016].

[3]. Bairagi, Dr Subir (2015). A research fellow of the Centre for Policy Dialogue (CPD). Published in Dhaka Tribune on Thursday, 24 December 2015. Available at http://cpd.org.bd/dr-subir-bairagi-on-bangladesh-poultry-sector-cited/. [Accessed 16 November 2016].

[4]. Bangladesh Bank Website (2016). Available at https://www.bb.org.bd/fnansys/bankfi.php.

[5]. Banglapedia (2016). Available at http://en.banglapedia.org/index.php?title=Livestock. [Accessed 16 November 2016].

[6]. Banglapedia (2016). Available at http://en.banglapedia.org/index.php?title=Main_Page. [Accessed 16 November 2016]

[7]. Bangladesh Poultry Directory (2013).

[8]. Bhuiyan, A. K. F. H. (2011). Implementation of National Livestock Development Policy (2007) and National Poultry Development Policy (2008): Impact on Smallholder Livestock Rearers. Keynote Paper Presented at the South Asia Pro Poor Livestock Policy Programme (SAPPLP)-BARC Worshop held at BRAC Center Inn, Dhaka.

[9]. Blri.gov.bd. Available at http://www.blri.gov.bd. [Accessed 17 November 2016].

[10]. Boddington, Michael (2007). Bangladesh Poultry Sub-Sector Report. IDE and Katalyst.

[11]. Boi (2013). Available at www.boi.gov.bd. [Accessed 18 November 2016].

[12]. Deloitte.com (2016). Deloitte.com (2016). Available at https://dupress.deloitte.com/dup-us-en/focus/business-trends/2015/business-ecosystems-comeof-age-business-trends.html. [Accessed 25 December 2016].

[13]. Dls.gov.bd. Available at old.dls.gov.bd/files/Livestock_Policy_Final.pdf. [Accessed 30 November 2016]

[14]. Dolberg, Frands (2008). Poultry Sector Country Review. Food and Agriculture Organization of the United Nations (FAO), August 2008. Pp.7, 33.

[15]. Eongroup (2016). Available at http://www.eongroup.net.bd. Accessed 04 December 2016.

[16]. Financial Express (2012). Available at http://print.thefinancialexpress-bd.com/old/more.php?news_id=127582\&date=2012-04-23. [Accessed 01 December 2016]

[17]. Financial Express (2012). Available at http://print.thefinancialexpress-bd.com/old/more.php?news_id=141300\&date=2012-08-27. [Accessed 01 December 2016].

[18]. Globalmeatnews.com (2016). Bangladesh to tighten regulation on foreign poultry giants. Available at

[19]. http://www.globalmeatnews.com/Retail/Bangladesh-to-tighten-regulation-on-foreign-poultry-giants. [Accessed 13 December 2016].

[20]. Government of the People's Republic of Bangladesh (2007). Available at 1. [Accessed 16 November 2016].

[21]. Government of the People's Republic of Bangladesh (2016). Available at http://www.flid.gov.bd/\#. [Accessed 16 November 2016]

[22]. Gupta, Sunil and Lehman, Donald R. (2003). Customer As Asset. Journal of Interactive Marketing. Vol. 17, No. 1, p. 9.

[23]. Heikkila and Kuivaniemi (2012). Ecosystem under Construction: An Action Research Study on Entrepreneurship in a Business Ecosystem. Technology Innovation Management Review. June 2012. Available at https://timreview.ca/.../HeikkilaKuivaniemi_TIMReview_June2012.pdf.

[24]. Huque, Khan Shahidul; Salequ, M. A.; Khatun, Razia (2016). Commercial Poultry in Bangladesh. Available at wpsa-bb.com/wpcontent/uploads/2016/04/Keynote-Paper-7th.pdf. [Accessed 29 October 2016]

[25]. keystonestrategy.com (2016). Available at http://keystonestrategy.com/business-ecosystems/. [Accessed 25 December 2016].

[26]. Khaled, Sarwar Md. Saifullah (2014). The Financial Express. Poultry industry: Realities and prospects Available at http://print.thefinancialexpressbd.com/2014/04/26/30787/print. Published 26 Apr, 2014 00:00:00. [Accessed 18 November 2016]. 
[27]. Kanter, Rosabeth Moss (2012). The Business Ecosystmem: A country can become complacent about its assets. Harvard Magazine. SeptemberOctober 2012. Available at http://harvardmagazine.com/2012/09/the-business-ecosystem. [Accessed 25 November 2016].

[28]. Khatun, Razia; Ahmed, Shamim; Hasan, Md. Amirul; Islam, Md. Saiful; Uddin, A. S. M. Ashab; Mahmud, Mohammad Showkat (2016). Value Chain Analysis of Processed Poultry Products (Egg and Meat) in Some Selected Areas of Bangladesh. American Journal of Rural Development. Vol. 4, No. 3, 2016, pp 65-70. doi: 10.12691/ajrd-4-3-2. Available at http://pubs.sciepub.com/ajrd/4/3/2/. [Accessed 29 October 2016]

[29]. Kotler, Philip (2001). Marketing Management. (10 ${ }^{\text {th }}$ Edition). New Jersey: Prentice-Hall, Inc.

[30]. Lengnick-Hall and Wolff (1999). Similarities and Contradictions in the Core Logic of thre Strategy Research Streams. Strategic Management Journal. 20(12), 1109 - 1132. Available at www.ipedr.com/vol52/017-ICEME2012-C00033.pdf.

[31]. Membership Directory (2013). Animal Health Companies Association of Bangladesh. $4^{\text {th }}$ Edition.

[32]. Mof.gov.bd. Available at www.mof.gov.bd/.../28\%20Chapter\%2030_44_Ministry\%20of\%20Fisheries_English.pdf. [Accessed 29 November 2016]

[33]. Moore, J. F. (1993). Predators and Prey: The New Ecology of Competition. Harvard Business Review. Vol. 71(3), pp. 75-83. Available at https://www.researchgate.net/.../228985086_Business_Ecosystem_as_the_New_Approach_to_Complex_Adaptive_Business_Environments.

[34]. Porter, Michael E. (1979). "How Competitive Forces Shape Strategy". Harvard Business Review. 57, No. 2, March - April 1979, pp. 137 - 45.

[35]. Porter, Michael E. (2008). "The Five Competitive Forces That Shape Strategy". Harvard Business Review. 86, No. 1 (January 2008$)$ pp. 80 - 86.

[36]. Probenewsmagazine (2011). Available at http://webcache.googleusercontent.com/search?q=cache:ebrIqZ7405sJ:http://vetsbd.com/wpcontent/uploads/2012/04/Article-on-Poultry-in-the PROBE.pdf\%2BForeign+poultry+farms + in + bangladesh \&hl=en-BD\&gbv=1\&ct=clnk. [Accessed 01 November 2016]

[37]. Raha, S.K. (n.d.). Poultry Industry in Bangladesh: Present Status and Future Potential. Available at bea-bd.org/site/images/pdf/084.pdf. [Accessed 18 November 2016].

[38]. Saleque and Saha 2013

[39]. Sarker, B. C., Alam, M. A., Rahman, M.M., Islam, Tariqul A. F. M. and Chowdhury M.G.F. (2009). Waste Management of Commercial Poultry Farms in Bangladesh. j. innov.dev.strategy 2(3): 34-37. Available at https://www.researchgate.net/publication/237770377_WASTE MANAGEMENT_OF_COMMERCIAL_POULTRY_FARMS_IN_BANGLADESH.

[40]. Sau (2016). Available at http://www.sau.edu.bd/index.php/department/home/DPS. [Accessed 16 November 2016].

[41]. Shah, S., Sharmin, M. and Hider, S. (not dated). Problems of Small to Medium Size Poultry Farms - Bangladesh Perspectie. Paper presented at EPC 2006 - XII European Poutry conference, Verona, Italy, 10 - 14 Septemeber, 2006. Available at http://www.animalsscience.com/uploads/additionalfiles/WPSAVerona\%5C10793.pdf. [4 July 2008]

[42]. Suzanne L. MacLachlan, "Son Now Beats Perdue Drumstick," Christian Science Monitor, March 9, 1995, p. 9; Sharon Nelton, "Crowing over Leadership Succession,” Nation's Business, May 1995, p. 52.

[43]. The Daily Star (2015). Available at http://www.thedailystar.net/business/processed-chicken-market-heat-71871. [Accessed 13 December 2016]

[44]. The Independent (2015). Available at http://www.theindependentbd.com/printversion/details/1653. [Accessed 09 December 2016].

[45]. Thomson, A., Peteraf Margaret A., Gamble, John E., Strickland, A.J., Jain, A.K. (2012). Crafting and Executing Strategy, The Quest for Competitive advantage, Concepts and Cases. (18 ${ }^{\text {th }}$ Edition). New Delhi: Tata McGraw Hill Education Private Limited.

[46]. Thepoultrysite (2016). Available at http://www.thepoultrysite.com/articles/2634/highlights-of-health-and-management-practices-on-breeder-chickenfarms-in-the-united-states-2010/. [Accessed 4 December 2016].

[47]. World Bank. February 10, 2009. What is Inclusive Growth? Available at siteresources.worldbank.org/.../WhatIsInclusiveGrowth20081230.pdf. [Accessed 28 November 2016].

[48]. Yamazaki, M. (2003). The Development Process of the Extension of Soybean production in Bangladesh: Collaboration between GO and NGOs. Research Bulletin. Vol. $\quad 34 . \quad$ Keisen College Horticulture, of http://nels.nii.ac.jp/els/110000483276.pdf?id=ART0000872351\&type=pdf\&lang=en\&host=cinii\&order $\quad$ no=\&ppv type=0\&lang $\mathrm{sw}=\& \mathrm{no}=1219396488 \& \mathrm{cp}=($ August 22,2008$)$. 